\title{
Fipronil Poisoning Presenting as Sinus Bradycardia - A Rare Case Report
}

\author{
Abhijit Wadekar ${ }^{1}$, Sreekarthik Pratapa ${ }^{2}$, Maharshi Patel ${ }^{3}$, Shilpa Gaidhane ${ }^{4}$, Nazli Khatib ${ }^{5}$, \\ 1, 2, 3,4 Department of Medicine, Acharya Vinoba Bhave Rural Hospital, Sawangi, Wardha, Maharashtra, India. \\ ${ }^{5}$ Department of Physiology, Acharya Vinoba Bhave Rural Hospital, Sawangi, Wardha, Maharashtra, India.
}

\section{INTRODUCTION}

Fipronil is an N-phenylpyrazole insecticide, a second-generation insecticide which is relatively new and now commonly used in cotton growing community of rural Central India. Farmer suicide and deliberate self-poisoning is menace to the Vidarbha region of rural Central India. There is paucity of research published on fipronil poisoning, clinical features, complications and treatment data. It is scarcely documented worldwide.

Agricultural insecticides are common household items in rural areas of developing countries. Because of their easy availability, insecticides became a major source of deliberate self-poisoning. As per World Health Organization (WHO), around 3 million poisoning cases with around 0.2 million deaths are noted annually in the world. ${ }^{1}$ About $99 \%$ of these deaths occur in developing countries. Insecticide poisoning is an important public issue in India. Around 168,000 deaths occurred from pesticide self-poisoning which totals to almost $19.7 \%$ of the global suicides. ${ }^{2}$ The most common cause of self-poisoning in Central India is ingestion of organophosphorus compounds (OPC). Poisoning with organophosphorus compound insecticides has high mortality rate. ${ }^{1}$

In the last 20 years, there is development of a new class of insecticides in view of mortality due to accidental exposures of organophosphorus and organochlorine compounds. Fipronil being one of these chemicals, is considered less harmful to humans. According to WHO classification fipronil is class II moderately hazardous pesticide. ${ }^{3}$ Fipronil, an N-phenylpyrazole with a trifluoromethyl sulfinyl substituent, one of the first second generation insecticides, acts at the $\gamma$-aminobutyric acid (GABA) receptor and blocks the chloride channel. Fipronil is often used to control pests, fleas and ticks on pets. There is, however, very less evidence or research on human beings on their toxicity; thus, post marketing surveillance is important to detect any undesirable health issues associated with these chemicals. Until now only 3 case reports are published regarding fipronil poisoning, two cases form India and others from Sri Lanka. Hence, we are reporting a case of acute fipronil poisoning which presented as acute gastritis and sinus bradycardia.

\author{
Corresponding Author: \\ Dr. Shilpa Gaidhane, \\ Department of Medicine, \\ Acharya Vinoba Bhave Rural Hospital, \\ Sawangi, Wardha, Maharashtra, India. \\ E-mail: dr.shilpagaidhane@gmail.com
}

DOI: $10.14260 / j e m d s / 2021 / 247$

How to Cite This Article: Wadekar A, Pratapa S, Patel M, et al. Fipronil poisoning presenting as sinus bradycardia - a rare case report.J Evolution Med Dent Sci 2021;10(16):1166-1168, DOI: 10.14260/jemds/2021/247

Submission 20-11-2020,

Peer Review 19-02-2021,

Acceptance 26-02-2021,

Published 19-04-2021.

Copyright (c) 2021 Abhijit Wadekar et al. This is an open access article distributed under Creative Commons Attribution License [Attribution 4.0 International (CC BY 4.0)] 


\section{PRESENTATION OF CASE}

A 30-year-old female patient, homemaker was brought by her sister to our emergency department with an alleged history of consumption of insecticide (fipronil $5 \%$ ) of around one and half glass (nearly $250 \mathrm{ml}$ ). Post consumption, patient had two episodes of vomiting which were foul smelling liquid, nonbilious, yellow in colour and containing food particles. She has consumed the insecticide due to dispute with her husband. Patient did not report any other complaints. On examination she was conscious and oriented to time place and person. Her heart rate was - 56 / min, regular, with respiratory rate of 18 / min and blood pressure of 120 / $70 \mathrm{~mm}$ of $\mathrm{Hg}$. Pupils were normal in size, reacting to light, on per abdominal examination, she had epigastric tenderness. On examination of central nervous system, higher function, cranial nerve function and motor nerve function were found to be normal. Her blood investigations revealed haemoglobin $9.8 \mathrm{~g} / \mathrm{dl}$, leucocyte count 9100 / cumm, platelets were 299,000 / cumm, peripheral blood smear was normal. Her blood urea was $19 \mathrm{mg}$ / dl, serum creatinine was $0.7 \mathrm{mg}$ / $\mathrm{dl}$, serum bilirubin $0.9 \mathrm{mg}$ / dl, ALT:14 U / L, AST:28 U / L coagulation parameters were normal, urine examination showed: urine albumin-nil, urine sugar-nil, epithelial cells-1-2 cells / hpf. Blood fipronil level was in view of bradycardia, her thyroid profile and echocardiography were done and found to be normal. Patient was monitored daily for seizures, hepatotoxicity coagulation profile and kidney function test. All were found to be normal throughout the stay of five days. Her heart rate increased gradually without any medications. Patient psychiatric counseling and couple counseling was done.

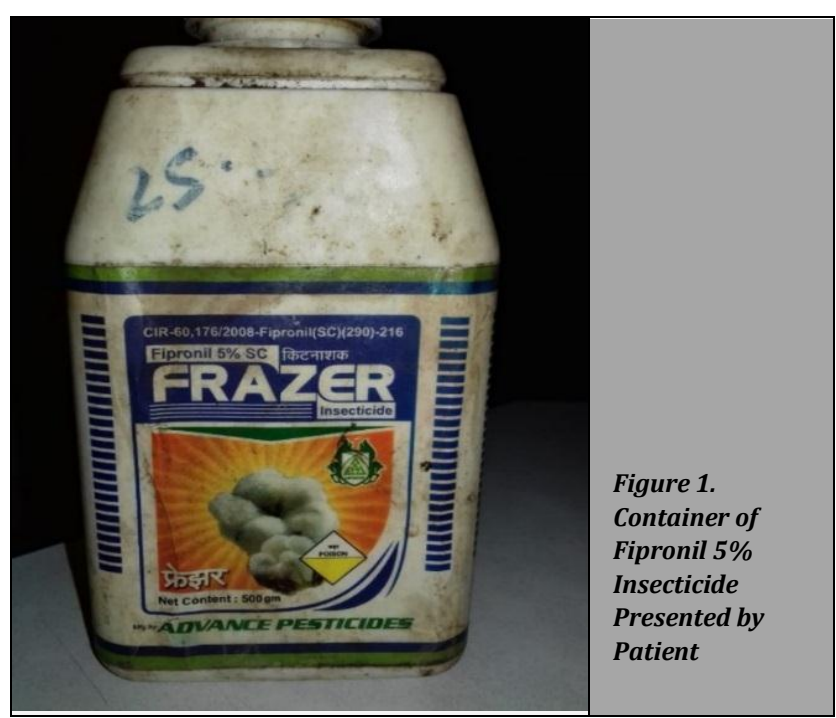

\section{DISCUSSION}

\section{Epidemiology}

So far only three research articles have been published regarding fipronil poisoning. With increasing use of secondgeneration insecticide in the cotton growing community of rural Central India, there is need to document the various presenting features of fipronil poisoning, treatment and outcome of fipronil poisoning. Here we are presenting an case of fipronil poisoning which presented as acute gastritis with sinus bradycardia.

Fipronil (CAS 120068-37-3, MW 437.16) is a relatively recent trifluoromethyl sulfonyl-mounted insecticide. Fipronil is used in liquid termiticides, as well as in agriculture, in granular turf products, seed treatments, topical pet care products.

It is used on crops to combat locusts, grasshoppers, fleas, ticks, cockroaches, ants, termites, weevils, and other insects. Cases of fipronil poisoning are not very common and very few cases are reported so far worldwide. Fipronil being newer compound, more research and reports are necessary. ${ }^{3}$

\section{Mechanism of Action}

Fipronil acts on Gaba channels restricting chloride ions to pass through these GABA-gated chloride channels, which results in hyperexcitability. Fipronil is toxic to insect by ingestion or contact. It inhibits Gaba aminobutyric acid gated chloride channels and glutamate-gated channels which causes excess neuronal activation thus, causing significant neurotoxicity. Fipronil shows differential affinity to receptors, affinity to insect receptors being higher than the mammalian receptors. ${ }^{4,5}$ Fipronil sulfone, metabolite of fipronil has six times potent action in blocking vertebrate GABA gated channels. Active metabolites of fipronil are fipronil sulfide, disulfinyl, and sulfone. Another mechanism of action of fipronil involves metabolic enzymatic systems which usually has sulfhydryl groups. Fipronil disrupts these systems resulting in uncoupling of oxidative phosphorylation in mitochondria which subsequently causes ischemia, resulting in hypoxia in vital organs leading to death 6,7

\section{Clinical Features of Fipronil Poisoning}

Post exposure presentation of fipronil poisoning in humans vary in terms of symptoms, which include sweating, gastritis symptoms like nausea and vomiting, pain in abdomen, neurological symptoms like dizziness, agitation, headache, and seizures which are mostly tonic clonic.3,8 Clinical features of exposure to fipronil are usually reversible and they tend to resolve spontaneously. Our case had mild symptoms like nausea, vomiting and dizziness which was resolved after symptomatic management, there were no symptoms after 2 days of treatment. According to literature available regarding fipronil poisoning, most patients showed mild clinical symptoms which were temporary and comprised most commonly neurological symptoms like paraesthesia, dizziness and headache, other less commonly involved systems were gastrointestinal, respiratory and ocular and renal. ${ }^{9}$

\section{Treatment and outcome}

Our study indicates that fipronil poisoning can present as mild and temporary undesirable effects on human body systems. Signs and symptoms of fipronil poisoning are generally reversible and resolve spontaneously with supportive treatment.

Few cases in the literature which were presented with seizure, were managed with benzodiazepines as standard practice first line management, along with supportive management of airway protection, oxygen supplementation. 
This was followed by phenobarbital infusion in case of status epilepticus. Gastric lavage as of gastric emptying procedure is of no value as fipronil has low toxicity and gastric lavage showed poor efficacy. ${ }^{12}$

Our patient did not develop neurological symptoms, hepatotoxicity and acute kidney injury, this may be due to the fact that patient has consumed less amount of insecticide. And was brought to emergency department promptly.

\begin{tabular}{|c|c|c|c|}
\hline Author & Presentation & Treatment & Outcome \\
\hline $\begin{array}{l}\text { Present } \\
\text { study }\end{array}$ & $\begin{array}{l}\text { Acute gastritis with sinus } \\
\text { bradycardia }\end{array}$ & $\begin{array}{c}\text { Gastric lavage supportive } \\
\text { management }\end{array}$ & $\begin{array}{l}\text { Complete } \\
\text { recovery }\end{array}$ \\
\hline $\begin{array}{l}\text { Gutta S, et } \\
\text { al. }^{10}\end{array}$ & $\begin{array}{l}\text { Acute neurotoxicity and } \\
\text { delayed hepatotoxicity }\end{array}$ & $\begin{array}{c}\text { Antiepileptics (phenytoin, } \\
\text { levetiracetam, clobazam) } \\
\text { atypical antipsychotics } \\
\text { (quetiapine) }\end{array}$ & $\begin{array}{l}\text { Complete } \\
\text { recovery by } \\
\text { third week }\end{array}$ \\
\hline $\begin{array}{l}\text { Yadla M, et } \\
\quad \text { al. }^{11}\end{array}$ & Status epilepticus anuria & $\begin{array}{c}\text { Haemodialysis, } \\
\text { conservative measures. }\end{array}$ & $\begin{array}{l}\text { AKI partially } \\
\text { reversed. serum } \\
\text { creatinine }\end{array}$ \\
\hline \multirow{4}{*}{$\begin{array}{l}\text { Mohamed F, } \\
\text { et al. }{ }^{3}\end{array}$} & $\begin{array}{c}\text { Case- } 1 \text {. } \\
\text { case 3, case } 4 \text {, case } 5 \text {, case } \\
\text { 7: asymptomatic } \\
\text { presentation }\end{array}$ & Supportive management & $\begin{array}{l}\text { Complete } \\
\text { recovery }\end{array}$ \\
\hline & $\begin{array}{c}\text { Case-2. } \\
\text { Drowsy, sweating } \\
\text { profusely, vomiting GTCS } \\
\text { lasting for } 1 \text { minute. }\end{array}$ & Diazepam 10 mg IV, & $\begin{array}{l}\text { Complete } \\
\text { recovery }\end{array}$ \\
\hline & $\begin{array}{c}\text { Case-6. } \\
\text { Acute gastritis }\end{array}$ & Forced emesis & $\begin{array}{l}\text { Complete } \\
\text { recovery }\end{array}$ \\
\hline & $\begin{array}{c}\text { Case-8. } \\
\text { Status epilepticus }\end{array}$ & $\begin{array}{l}\text { Intubation, } \\
\text { benzodiazepines, } \\
\text { phenobarbital }\end{array}$ & $\begin{array}{l}\text { Pneumonia and } \\
\text { died without } \\
\text { regaining } \\
\text { consciousness }\end{array}$ \\
\hline
\end{tabular}

Financial or other competing interests: None.

Disclosure forms provided by the authors are available with the full text of this article at jemds.com.

\section{REFERENCES}

[1] Jeyaratnam J. Acute pesticide poisoning: a major global health problem. World Health Stat Q 1990;43(3):139-44.
[2] Mew EJ, Padmanathan P, Konradsen F, et al. The global burden of fatal self-poisoning with pesticides 2006-15: systematic review. J Affect Disord 2017;219:93-104.

[3] Mohamed F, Senarathna L, Percy A, et al. Acute human self-poisoning with the $\mathrm{N}$-phenylpyrazole insecticide fipronil--A GABAA-gated chloride channel blocker. J Toxicol Clin Toxicol 2004;42(7):955-63.

[4] Ratra GS, Casida JE. GABA receptor subunit composition relative to insecticide potency and selectivity. Toxicol Lett 2001;122(3):215-22.

[5] Ratra GS, Erkkila BE, Weiss DS, et al. Unique insecticide specificity of human homomeric rho $1 \mathrm{GABA}(\mathrm{C})$ receptor. Toxicol Lett 2002;129(1-2):47-53.

[6] Vidau C, González-Polo RA, Niso-Santano M, et al. Fipronil is a powerful uncoupler of oxidative phosphorylation that triggers apoptosis in human neuronal cell line SHSY5Y. Neurotoxicology 2011;32(6):935-43.

[7] Hainzl D, Cole LM, Casida JE. Mechanisms for selective toxicity of fipronil insecticide and its sulfone metabolite and desulfinyl photoproduct. Chem Res Toxicol 1998;11(12):1529-35.

[8] Chodorowski Z, Anand JS. Accidental dermal and inhalation exposure with fipronil--a case report. J Toxicol Clin Toxicol 2004;42(2):189-90.

[9] Lee SJ, Mulay P, Diebolt-Brown B, et al. Acute illnesses associated with exposure to fipronil--surveillance data from 11 states in the United States, 2001-2007. Clin Toxicol (Phila) 2010;48(7):737-44.

[10] Gutta S, Prasad JD, Gunasekaran K, et al. Hepatotoxicity and neurotoxicity of Fipronil poisoning in human: a case report. J Family Med Prim Care 2019;8(10):3437-9.

[11] Yadla M, Sailaja S, Ahmed N, et al. An unusual case of insecticide poisoning presenting as acute kidney injury. Saudi J Kidney Dis Transpl 2017;28(6):1432-4.

[12] Vale JA. Position statement: gastric lavage. American Academy of Clinical Toxicology; European Association of Poisons Centres and Clinical Toxicologists. J Toxicol Clin Toxicol 1997;35(7):711-9. 